\title{
Selective and sensitive method for the determination of metoprolol in human plasma using liquid chromatography coupled with tandem mass spectrometry
}

\author{
PADALA VENKATESWARLU ${ }^{1}$ \\ BOMMANA NARESH KUMAR ${ }^{1}$ \\ KALLURU SESHAIAH ${ }^{1, *}$ \\ VASIREDDY VEERA VARA PRASAD ${ }^{2}$ \\ 1 Analytical Chemistry Division \\ Department of Chemistry \\ Sri Venkateswara University \\ Tirupati-517502, India \\ ${ }^{2}$ Bio-Analytical Division \\ Vimta Labs Limited, Cherlapally \\ Hyderabad-500051, India
}

\begin{abstract}
A high-performance liquid chromatography-tandem mass spectrometric method was developed and validated for the determination of metoprolol in human plasma. The analyte and internal standard, nevirapine, were extracted from plasma matrix by liquid-liquid extraction with ethyl acetate. Chromatographic separation was achieved on a C-18 analytical column with an isocratic mobile phase of 15:85 ( $V / V) 10 \mathrm{mmol} \mathrm{L}^{-1}$ ammonium acetate $(\mathrm{pH} 5.0) /$ acetonitrile. The atmospheric pressure chemical ionization technique was used for sample ionization in positive ion mode and enhanced selectivity was achieved by tandem mass spectrometric analysis via two multiple reaction monitoring (MRM) transitions, $268.2 \rightarrow$ 116.2 for metoprolol and $267.1 \rightarrow 226.2$ for nevirapine, respectively. The assay was validated for human plasma over a concentration range of $1-200 \mathrm{ng} \mathrm{mL}^{-1}$ with the precision and accuracy ranging from 0.9 to $8.8 \%$ and 89.9 to $105.8 \%$, respectively.
\end{abstract}

Keywords: metoprolol, liquid chromatography, tandem mass spectrometry, human plasma, bioequivalence

Metoprolol, 1-isopropylamino-3-[4-(2-methoxy-ethyl)-phenoxy]-2-propanol, is a $\beta 1$ -selective aryloxy propanolamine used in the treatment of cardiovascular disorders such as hypertension, arrhythmia and heart failure (1). The drug is a lipophilic adrenoreceptor antagonist ( $\beta$-blocker) with a short half-life.

Various methods reported for the determination of metoprolol and its metabolites in human plasma include gas chromatography (GC) equipped with an electron capture detector (ECD) (2), nitrogen selective detector (NSD) (3), mass spectrometry (MS) detector $(4,5)$ and high performance liquid chromatography equipped with a ultra violet detector $(6,7)$, fluorescence detector (8-12), MS detector (13-15). Sample preparation for the extraction of metoprolol from human plasma is based on the solid phase extraction (4) and liquid-liquid extraction using dichloro methane $(2,8,10,12)$, n-butyl chloride (11) and mixture of dichloromethane and diethyl ether $(2,8)$.

\footnotetext{
* Correspondence; e-mail: seshaiahsvu@yahoo.co.in
} 
P. Venkateswarlu et al.: Selective and sensitive method for the determination of metoprolol in human plasma using liquid chromatography coupled with tandem mass spectrometry, Acta Pharm. 60 (2010) 177-184.

In the present work we developed a reverse phase liquid chromatography and tandem mass spectrometric method which is more sensitive (LOQ of $1 \mathrm{ng} \mathrm{mL}^{-1}$ ) than the methods reported in the literature using less plasma sample volume $(100 \mu \mathrm{L})$. The liquid-liquid extraction method was used for extraction of analyte and internal standard, which is time saving. The method was validated by evaluating parameters such as the linearity of chromatographic response, precision, accuracy.

\section{EXPERIMENTAL}

\section{Chemicals}

Metoprolol succinate obtained from Degussa (India), nevirapine from Cipla, (India), ethyl acetate (AR grade) from Qualigens (India), ammonium acetate (AR grade) from Merck (India), acetonitrile and water (HPLC grade) from Merck (India) were used in this analysis. $\mathrm{K}_{3}$ HEDTA (Sigma Aldrich, India) was used as anti-coagulant.

\section{Instrumentation and LC-MS/MS conditions}

The HPLC system consisted of an Agilent Technologies 1100 series system equipped with a binary pump, vacuum degasser, column oven and an auto sampler (Agilent Technologies Inc, USA). Mass spectrometric detection was performed using an API 3200 (triple quadrupole) instrument from Applied Bio Systems (MDS SCIEX, Canada) with an APCI interface. The data acquisition and control system was created using the Analyst 1.4.2 software from Applied Bio Systems. The main working parameters of the mass spectrometer are summarized in Table I. Nitrogen was produced using an on-site nitrogen generator from PEAK Scientific, UK. A C18 analytical column (Purospher Star, $4.6 \times 150$ $\mathrm{mm}, 5 \mu \mathrm{m}$ ) (Merck) was used. All chromatography experiments were carried out in iso-

Table I. Tandem mass spectrometer main working parameters

\begin{tabular}{lc}
\hline \multicolumn{1}{c}{ Parameter } & Value \\
\hline Source temperature $\left({ }^{\circ} \mathrm{C}\right)$ & 500 \\
Dwell time per transition $(\mathrm{ms})$ & 200 \\
Source gas $(\mathrm{Pa})$ & 344740 \\
Curtain gas $(\mathrm{Pa})$ & 137896 \\
Collision gas $(\mathrm{Pa})$ & 20684 \\
Nebulizer current $(\mu \mathrm{A})$ & 5 \\
Declustering potential $(\mathrm{V})$ & 50 (analyte), 52 (IS) \\
Collision energy $(\mathrm{V})$ & 25 (analyte), 35 (IS) \\
Collision cell exit potential $(\mathrm{V})$ & 3 (analyte), 7 (IS) \\
Mode of analysis & Positive \\
Ion transitions for metoprolol $(\mathrm{m} / \mathrm{z})$ & $268.2 \rightarrow 116.2$ \\
Ion transitions for nevirapine $(\mathrm{m} / \mathrm{z})$ & $267.1 \rightarrow 226.2$ \\
\hline
\end{tabular}


P. Venkateswarlu et al.: Selective and sensitive method for the determination of metoprolol in human plasma using liquid chromatography coupled with tandem mass spectrometry, Acta Pharm. 60 (2010) 177-184.

cratic mode. The mobile phase, consisting of $10 \mathrm{mmol} \mathrm{L}^{-1}$ ammonium acetate ( $\mathrm{pH}$ 5.0)/ acetonitrile $(15: 85, V / V)$ was pumped at a flow rate of $1 \mathrm{~mL} \mathrm{~min}^{-1}$. The injection volume was $20 \mu \mathrm{L}$ and the total run time was $3 \mathrm{~min}$.

\section{Preparation of standards and quality control samples}

Stock solutions of metoprolol $\left(1 \mathrm{mg} \mathrm{mL}^{-1}\right)$ and internal standard (IS) nevirapine (1 $\mathrm{mg} \mathrm{mL}^{-1}$ ) were separately prepared in $5-\mathrm{mL}$ volumetric flasks with acetonitrile. The internal standard working solution $\left(1 \mu \mathrm{g} \mathrm{mL}{ }^{-1}\right)$ was prepared by diluting its stock solution with water/acetonitrile (1:1). The working standard solution of metoprolol (50 $\mu \mathrm{L})$ was added to $950 \mu \mathrm{L}$ drug free plasma to obtain metoprolol concentration levels of $1,2,5,10$, 25, 50, 100 and $200 \mathrm{ng} \mathrm{mL}^{-1}$.

\section{Sample preparation}

The plasma sample $(100 \mu \mathrm{L})$ was transferred into a vial and then $10 \mu \mathrm{L}$ of internal standard $\left(1 \mu \mathrm{g} \mathrm{mL}^{-1}\right)$ working solution was added. After vortexing for $30 \mathrm{~s}, 2.5 \mathrm{~mL}$ of extraction solvent, ethyl acetate, was added to the sample. The samples were vortexed on a shaker for $10 \mathrm{~min}$ and the supernatant (organic layer) was transferred into another vial. Ethyl acetate layer was evaporated under a stream of nitrogen at $40{ }^{\circ} \mathrm{C}$. The dried residue was reconstituted with $100 \mu \mathrm{L}$ of mobile phase and vortexed. The sample was loaded into auto-injector vials and $20 \mu \mathrm{L}$ aliquots were injected into the chromatographic system.

\section{Method validation}

The selectivity of the method was determined by analyzing blank plasma, without addition of metoprolol and IS. Three analytical batches were used to assess the precision and accuracy of the method. Each batch contained a single set of calibration standards and six replicates of regular quality control (QC) samples at three concentrations $(3,80$ and $160 \mathrm{ng} \mathrm{mL}^{-1}$ ). The assay precision for each QC level was determined as the relative standard deviation (RSD) of the measured concentrations and the accuracy was expressed as percentage of the mean of measured concentrations over the nominal concentration. The intra- and inter-batch precisions were required to be below $15 \%$, and accuracy within $\pm 15 \%$. For LLOQ, the precision required should be below $20 \%$ and accuracy within $\pm 20 \%$ (16).

\section{RESULTS AND DISCUSSION}

\section{Method development}

Optimization of tandem mass spectrometry conditions. - Direct infusion method was used for optimization of compound parameters. Methanolic solutions of metoprolol and nevirapine at a concentration of $100 \mathrm{ng} \mathrm{mL}^{-1}$ were used. In this mode, the parent ion, source parameters such as ion spray voltage, curtain gas and compound parameters declustering potential, focusing potential were optimized, and then the product ion was 
P. Venkateswarlu et al.: Selective and sensitive method for the determination of metoprolol in human plasma using liquid chromatography coupled with tandem mass spectrometry, Acta Pharm. 60 (2010) 177-184.

optimized using product ion scan. Product ion formation was achieved by using collision gas. MRM scan mode was used for optimization of collision energy, collision cell exit potential. Flow injection analysis method was used for optimizing the source gas and source temperature. Here, $10 \mathrm{mmol} \mathrm{L}^{-1}$ ammonium acetate buffer and acetonitrile solution (15:85) was used at a $1.0 \mathrm{~mL} \mathrm{~min}^{-1}$ flow rate and without column. All optimized mass spectrometry parameters are summarized in Table I.

Optimization of chromatographic conditions. - The chromatographic conditions were optimized through several trials to achieve good resolution and symmetric peaks of analyte and IS as well as a short run time. The mobile phase pH 5 was found to be necessary for good sensitivity and peak shape. High proportion of organic solvent $[10 \mathrm{mmol} \mathrm{L}-1$ ammonium acetate ( $\mathrm{pH} 5.0)$ /acetonitrile $(15: 85, \mathrm{~V} / \mathrm{V})$ ] eluted the analyte and the IS at retention times of 1.64 and $1.75 \mathrm{~min}$, respectively.

Optimization of extraction. - Four organic solvents, diethyl ether, hexane, ethyl acetate and dichloromethane were used in the extraction process. Ethyl acetate was found to be optimal; it can produce a clean chromatogram for a blank plasma sample and yield the highest analyte recovery from the plasma.

\section{Method validation}

The selectivity of the method was examined by analyzing $(n=6)$ blank human plasma extracts. As shown in Fig. 1a, there was no significant interference in the blank plasma at analyte retention time. Fig. $1 \mathrm{~b}$ depicts a representative chromatogram for me-
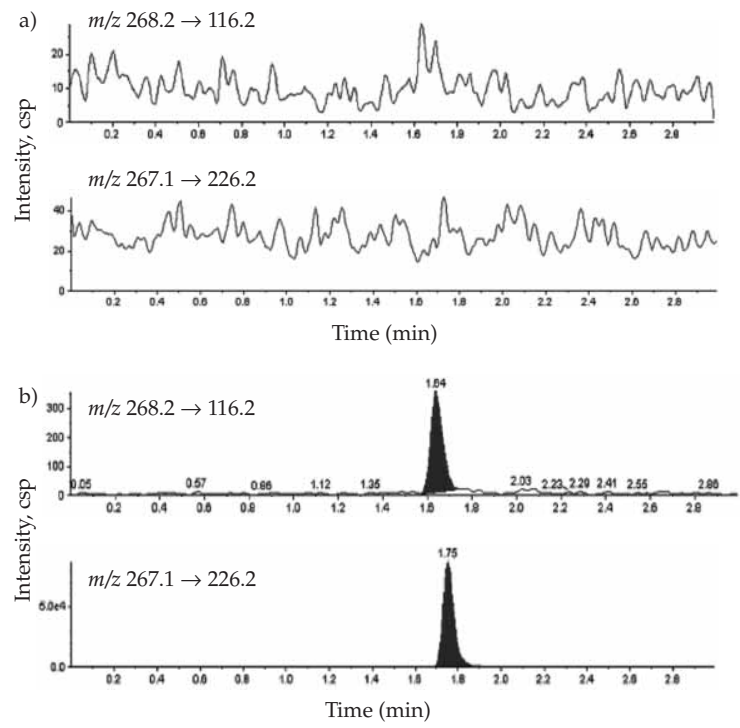

Fig. 1. MRM chromatograms of: a) blank (drug and IS free human plasma), b) plasma spiked with metoprolol at $L L O Q$ level $\left(1 \mathrm{ng} \mathrm{mL}^{-1}\right)$ and IS $\left(1 \mu \mathrm{g} \mathrm{mL} L^{-1}\right)$. 
P. Venkateswarlu et al.: Selective and sensitive method for the determination of metoprolol in human plasma using liquid chromatography coupled with tandem mass spectrometry, Acta Pharm. 60 (2010) 177-184.

toprolol at the $L L O Q$ level $\left(1 \mathrm{ng} \mathrm{mL}^{-1}\right)$. Excellent sensitivity was observed for a $20 \mu \mathrm{L}$ injection volume.

The eight-point calibration curve was linear over the concentration range 1-200 ng $\mathrm{mL}^{-1}$ metoprolol. The best linear fit and least-squares residuals for the calibration curve were achieved with a $1 / x$ weighing factor, giving the mean linear regression equation $y=0.0007 x+0.0050$ where $y$ is the peak area ratio of the metoprolol to the IS and $x$ is the metoprolol concentration (ng mL-1). The mean correlation coefficient of the weighted calibration curve generated during the validation was 0.9995 ( \pm 0.0003$)$; Table II summarizes the calibration data.

The $L L O Q$ was defined as the lowest concentration in the standard curve that can be measured with acceptable accuracy and precision and was found to be $1 \mathrm{ng} \mathrm{mL}-1$ in human plasma. The mean peak area for the analyte peak at LLOQ $\left(1 \mathrm{ng} \mathrm{mL}{ }^{-1}\right)$ was 10-fold greater than the mean peak area for the blank human plasma samples at the analyte retention time. The imprecision and accuracy at $L L O Q$ level were 9.2 and $90.2 \%$. For the within-batch experiments, the repeatability RSD and accuracy ranged from 0.9 to $8.8 \%$ and accuracy from 89.9 to $105.8 \%$ as shown in Table III.

Recovery of the metoprolol from the extraction procedure was examined by comparing the detector response obtained from the processed (extracted) sample and the detector response obtained for direct injection of standard solution. Recovery experiment was performed at three concentration levels (low, medium and high) with six replicates. The mean recovery for metoprolol at three different concentrations was $78.0 \%$. The recovery of IS was $77.6 \%$ at the concentration used in the assay $\left(100 \mathrm{ng} \mathrm{mL}^{-1}\right)$. The recovery of analyte and IS was consistent.

The analytical performance of the proposed method for the determination of metoprolol in human plasma was compared with HPLC methods reported in the literature and the values are presented in Table IV. These values indicate that the present method has several advantages over the reported methods in terms of the plasma volume used for extraction, total run time, recovery of metoprolol and LOQ. For example Gowda et al.

Table II. Precision and accuracy data of back-calculated concentrations of calibration standards for metoprolol in human plasma

\begin{tabular}{cccc}
\hline $\begin{array}{c}\text { Concentration added to } \\
\text { blank plasma }\left(\mathrm{ng} \mathrm{mL}^{-1}\right)\end{array}$ & $\begin{array}{c}\text { Concentration found } \\
\left(\mathrm{ng} \mathrm{mL}^{-1}\right)^{\mathrm{a}}\end{array}$ & Precision (RSD, \%) & Accuracy $(\%)$ \\
\hline 1.01 & $0.97 \pm 0.084$ & 8.7 & 95.9 \\
2.02 & $2.01 \pm 0.140$ & 7.0 & 99.2 \\
5.05 & $5.17 \pm 0.184$ & 3.6 & 102.4 \\
10.10 & $10.01 \pm 0.555$ & 5.5 & 99.1 \\
25.25 & $25.31 \pm 0.767$ & 3.0 & 100.2 \\
50.50 & $51.72 \pm 0.716$ & 1.4 & 102.4 \\
101.01 & $103.49 \pm 2.414$ & 2.3 & 102.5 \\
202.01 & $198.28 \pm 3.735$ & 1.9 & 98.2 \\
\hline
\end{tabular}

\footnotetext{
a Mean $\pm \mathrm{SD}, n=5$.
} 
P. Venkateswarlu et al.: Selective and sensitive method for the determination of metoprolol in human plasma using liquid chromatography coupled with tandem mass spectrometry, Acta Pharm. 60 (2010) 177-184.

Table III. Precision and accuracy data of the LC-MS/MS method for determining in human plasma samples

\begin{tabular}{ccccc}
\hline & $\begin{array}{c}\text { Concentration } \\
\left(\mathrm{ng} \mathrm{mL}^{-1}\right)\end{array}$ & $\begin{array}{c}\text { Concentration found } \\
\left(\mathrm{ng} \mathrm{mL}^{-1}\right)^{\mathrm{a}}\end{array}$ & Precision (RSD, \%) & Accuracy (\%) \\
\hline Batch 1 & 3.03 & $3.05 \pm 0.267$ & 8.8 & 100.6 \\
& 80.86 & $85.53 \pm 5.495$ & 6.4 & 105.8 \\
Batch 2 & 161.72 & $164.86 \pm 12.076$ & 7.3 & 101.9 \\
& 3.03 & $2.79 \pm 0.092$ & 3.3 & 91.8 \\
Batch 3 & 80.86 & $73.06 \pm 1.841$ & 2.5 & 90.4 \\
& 161.72 & $145.39 \pm 1.863$ & 1.3 & 89.9 \\
& 3.03 & $2.92 \pm 0.111$ & 3.8 & 96.3 \\
Inter batch & 80.86 & $78.86 \pm 0.730$ & 0.9 & 97.5 \\
& 161.72 & $159.72 \pm 2.539$ & 1.6 & 98.8 \\
& 3.03 & $2.92 \pm 0.199$ & 6.8 & 96.2 \\
& 80.86 & $79.15 \pm 6.125$ & 7.7 & 97.9 \\
\hline
\end{tabular}

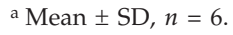

(14) reported LC-MS/MS method with limit of quantitation (LOQ) of $5 \mathrm{ng} \mathrm{mL}^{-1}$ for metoprolol by using $250 \mu \mathrm{L}$ of plasma for sample preparation.

In the present work we developed a reverse phase liquid chromatography and tandem mass spectrometric method which is more sensitive ( $L O Q$ of $1 \mathrm{ng} \mathrm{mL}^{-1}$ ) than the methods reported in the literature using less plasma sample volume $(100 \mu \mathrm{L})$.

Table IV. Comparision of analytical performances of the present method for metoprolol with HPLC methods reported in the literature

\begin{tabular}{|c|c|c|c|c|c|}
\hline Method of extraction & $\begin{array}{c}\text { Plasma volume } \\
\text { used in extraction } \\
(\mu \mathrm{L})\end{array}$ & $\begin{array}{l}\text { Recovery } \\
(\%)\end{array}$ & $\begin{array}{l}\text { Total run time } \\
\text { (minutes) }\end{array}$ & $\begin{array}{c}L O Q \\
\left(\mathrm{ng} \mathrm{mL}^{-1}\right)\end{array}$ & References \\
\hline LLE (ethyl acetate) & 500 & More than 77 & 40 & 25 & 6 \\
\hline $\begin{array}{l}\text { LLE (chloroform/penta- } \\
\text { nol/diethyl ether, 6:2:1) }\end{array}$ & 1000 & - & 26 & 25 & 7 \\
\hline SPE & 1000 & - & 14 & 1 & 9 \\
\hline LLE (dichloromethane) & 500 & - & - & 10 & 10 \\
\hline LLE (n-butyl chloride) & 1000 & 74 & 8 & 5 & 11 \\
\hline LLE (dichloromethane) & 1000 & - & 9 & 10 & 12 \\
\hline $\begin{array}{l}\text { LLE (diethyl ether/ } \\
\text { dicloromethane } 70: 30 \text { ) }\end{array}$ & 250 & 78 & 5 & 5 & 14 \\
\hline LLE (ethyl acetate) & 100 & 78 & 3 & 1 & this paper \\
\hline
\end{tabular}

LLE - liquid-liquid extraction; SPE - solid phase extraction. 
P. Venkateswarlu et al.: Selective and sensitive method for the determination of metoprolol in human plasma using liquid chromatography coupled with tandem mass spectrometry, Acta Pharm. 60 (2010) 177-184.

\section{CONCLUSIONS}

A sensitive, accurate and precise method based on LC-MS/MS for the determination of metoprolol in human plasma with $L L O Q$ of $1 \mathrm{ng} \mathrm{mL^{-1 }}$ level is described. The method can be used for the determination of metoprolol in the range of 1-200 ng $\mathrm{mL}^{-1}$ in human plasma.

Acknowledgements. - The authors (K. Seshaiah and B. Naresh Kumar) are thankful to UGC, New Delhi, India, for financial support. The authors also thank M/s Vimta Labs Ltd., Cherlapalli, Hyderabad, India, for providing analytical facilities.

\section{REFERENCES}

1. J. Fang, H. A. Semple and J. Song, Determination of metoprolol, and its four metabolites in dog plasma, J. Chromatogr. B. 809 (2004) 9-14; DOI: 10.1016/j.jchromb.2004.05.029.

2. A. Sioufi, F. Leroux and N. Sandrenan, Gas chromatographic determination of metoprolol in human plasma, J. Chromatogr. B 272 (1983) 103-110; DOI: 10.1016/S0378-4347(00)86107-1.

3. O. Gyllenhaal and J. Vessman, Gas chromatography with nitrogen-selective detection of metoprolol from human plasma after reaction with phosgene, J. Chromatogr. B 273 (1983) 129-139; DOI: 10.1016/S0378-4347(00)80929-9.

4. M. P. Quaglio, A. M. Bellini, L. Minozzi, G. Frisina and F. Testoni, Simultaneous determination of propranolol or metoprolol in the presence of butyrophenones in human plasma by gas chromatography with mass spectrometry, J. Pharm. Sci. 82 (1993) 87-90; DOI: 10.1002/jps.2600820119.

5. D. Gaudry, D. Wantiez, J. Richard and J. P. Metayer, Simultaneous determination of metoprolol and deuterium-labelled metoprolol in human plasma by gas chromatography-negative-ion mass spectrometry, J. Chromatogr. B 339 (1985) 404-409; DOI: 10.1016/S0378-4347(00)84671-X.

6. Q. Li and R. Wang, Simultaneous analysis of tramadol, metoprolol and their metabolites in human plasma and urine by high performance liquid chromatography, Chin. Med. J. 119 (2006) 2013-2017.

7. M. Delamoye, C. Duverneuil, F. Paraire, P. De Mazancourt and J. C. Alvarez, Simultaneous determination of thirteen $\beta$-blockers and one metabolite by gradient high-performance liquid chromatography with photodiode-array UV detection, Forensic. Sci. Int. 141 (2004) 23-31; DOI: 10.1016/j.forsciint.2003.12.008.

8. J. B. Lecaillon, J. Godbillon, F. Abadie and G. Gosset, Determination of metoprolol and its $\alpha$-hydroxylated metabolite in human plasma by high-performance liquid chromatography, J. Chromatogr. B 305 (1984) 411-417; DOI :10.1016/S0378-4347(00)83355-1.

9. B. Mistry, J. Leslie and N. E. Eddington, A sensitive assay of metoprolol and its major metabolite $\alpha$-hydroxy metoprolol in human plasma and determination of dextromethorphan and its metabolite dextrorphan in urine with high performance liquid chromatography and fluorometric detection, J. Pharm. Biomed. Anal. 16 (1998) 1041-1049; DOI: 10.1016/S0731-7085(97)00115-5.

10. Y. Horai, T. Ishizaki, M. Kusaka, G. Tsujimoto and G. K. Hashimoto, Simultaneous determination of metoprolol and $\alpha$-hydroxymetoprolol in human plasma and urine by liquid chromatography with a preliminary observation on metoprolol oxidation in Japanese subjects, Ther. Drug Monit. 10 (1988) 428-433.

11. G. D. Johnston, A. S. Nies and J. Gal, Determination of metoprolol in human blood plasma using high-performance liquid chromatography, J. Chromatogr. B. 278 (1983) 204-208; DOI:10.1016/ S0378-4347(00)84776-3. 
P. Venkateswarlu et al.: Selective and sensitive method for the determination of metoprolol in human plasma using liquid chromatography coupled with tandem mass spectrometry, Acta Pharm. 60 (2010) 177-184.

12. M. S. Lennard and J. H. Silas, Rapid determination of metoprolol and $\alpha$-hydroxymetoprolol in human plasma and urine by high-performance liquid chromatography, J. Chromatogr. B 272 (1983) 205-209; DOI: 10.1016/S0378-4347(00)86120-4.

13. S. Li, G. Liu, J. Jia, Y. Liu, C. Pan, C. Yu, Y. Cai and J. Ren, Simultaneous determination of ten antiarrhythmic drugs and a metabolite in human plasma by liquid chromatography-tandem mass spectrometry, J. Chromatogr. B 847 (2007) 174-181; DOI: 10.1016/j.jchromb.2006.10.013.

14. K. V. Gowda, U. Mandal, P. Senthamil Selvan, W. D. Sam Solomon, A. Ghosh, A. K. Sarkar, S. Agarwal, T. Nageswar Rao and T. K. Pal, Liquid chromatography tandem mass spectrometry method for simultaneous determination of metoprolol tartrate and ramipril in human plasma, J. Chromatogr. B 858 (2007) 13-21; DOI: 10.1016/j.jchromb.2007.07.047.

15. B. P. Jensen, C. F. Sharp, S. J. Gardiner and E. J. Begg, Development and validation of a stereoselective liquid chromatography-tandem mass spectrometry assay for quantification of S-and R-metoprolol in human plasma, J. Chromatogr. B 865 (2008) 48-54; DOI: 10.1016/j.jchromb.2008. 02.006 .

16. US Department of Health and Human Services, FDA, CDER and CVM, Guidance for the Industry: Bioanalytical Method Validation, Washington (DC) 2001, p. 5.

\section{$S A \check{Z} E T A K$}

\section{Selektivna i osjetljiva metoda određivanja metoprolola u humanoj plazmi tekućinskom kromatografijom spregnutom s masenom spektrometrijom}

PADALA VENKATESWARLU, BOMMANA NARESH KUMAR, KALLURU SESHAIAH i VASI REDDY VERA VARA PRASAD

U radu je opisano određivanje metoprolola u humanoj plazmi tekućinskom kromatografijom visoke učinkovitosti spregnutom s masenom spektrometrijom. Analit i interni standard, nevirapin, ekstrahirani su iz plazme etil-acetatom. Kromatografsko odjeljivanje provedeno je na C-18 koloni uz mobilnu fazu sljedećeg sastava: $10 \mathrm{mmol} \mathrm{L}^{-1}$ amonijev acetat ( $\mathrm{pH} 5,0) /$ acetonitril 15:85 (V/V). Ionizacija uzoraka provedena je pri atmosferskom tlaku. Povećanje selektivnosti postignuto je spregnutom masenom spektrometrijskom analizom praćenjem dvaju prijelaza (MRM) - 268,2 $\rightarrow$ 116,2 za metoprolol, odnosno 267,1 $\rightarrow$ 226,2 za nevirapin. Metoda je validirana za koncentracijsko područje 1-200 ng mL $\mathrm{m}^{-1}$ uz preciznost i točnost od 0,9 do $8,8 \%$, odnosno 89,9 do $105,8 \%$.

Ključne riječi: metoprolol, tekućinska kromatografija, spregnuta masena spektrometrija, humana plazma, bioekvivalencija

Analytical Chemistry Division, Department of Chemistry, Sri Venkateswara University, Tirupati 517 502, India

Bio - Analytical Division, Vimta Labs Limited, Cherlapally, Hyderabad 500 051, India 